\author{
ステンレス鋼中のトリチウムの分布* \\ 鳥養 祐二*1 ·村田 大樹*1 $\cdot$ Ralf-Dieter PENZHORN*1 \\ 赤石 憲也*1 $\cdot$ 渡辺 国昭*1・松山 政夫*1
}

\title{
Tritium Depth Profiles in 316 Stainless Steel
}

\author{
Yuji TORIKAI, Daiju MURATA, Ralf-Dieter PENZHORN, \\ Kenya AKAISHI, Kuniaki WATANABE and Masao MATSUYAMA
}

Hydrogen Isotope Research Center, University of Toyama, Gofuku 3190, Toyama, 930-8555, Japan

(Received November 9, 2006, Accepted February 11, 2006)

\begin{abstract}
To investigate the behavior of hydrogen uptake and release by 316 stainless steel (SS316), as-received and finely polished stainless steel specimens were exposed at $573 \mathrm{~K}$ to tritium gas diluted with hydrogen. Then tritium concentration in the exposed specimens was measured as a function of depth using a chemical etching method. All the tritium concentration profiles showed a sharp drop in the range of $10 \mu \mathrm{m}$ from the top surface up to the bulk. The amount of tritium absorbed into the polished specimens was three times larger than that into the as-received specimen. However, the polishing effects disappeared by exposing to the air for a long time.
\end{abstract}

\section{1.はじめに}

ステンレス鋼は真空装置の構造材として広く用いられてい るが，超高真空用では低ガス放出率化が課題である。 また， ステンレス鋼は $\mathrm{D}+\mathrm{T}$ 核融合炉の本体やトリチウム取扱設 備の構造材として最有力な材料である1).この場合, トリチ ウムを含む水素同位体が構造材中に吸蔵されるので, トリチ ウムの污染が問題となる.

そこで，ステンレス鋼中のトリチウムの効率的な除染法の 開発を行うと共に，ステンレス鋼に抢ける水素の吸蔵-放出 挙動を明らかにする一環として, 高濃度のトリチウムガスを 用いてステンレス鋼へのトリチウムの吸蔵・放出実験を行っ ている. 本報告では, 表面処理の異なるステンレス鋼に対 し, 吸蔵された水素の深さ分布を, トリチウムを用いて可視 化したので報告する

\section{2. 実験}

\section{1 試料}

実験で使用した試料は，SS316ステンレス鋼であり，加工 サイズは $15 \mathrm{~mm}$ 角で, 厚さ $0.5 \mathrm{~mm}$ である.未処理の試料 (as-received : AR), 粒径0.06 $\mu \mathrm{m}$ のアルミナ粉末を用いて 研磨した試料 (polished : POL) および研磨後 1 ヶ月大気中 に放置した試料（re-oxidized：OX）の3 種類を用意し，そ れらを純水抢よびアセトンを用いて超音波洗浄した．Fig. 1 に AR 試料の SEM 写真を示す。写真からわかるように $\mathrm{AR}$ 試料では粒界と思われる数 $\mu \mathrm{m}$ から数十 $\mu \mathrm{m}$ の結晶粒界が観 察された. POL および OX 試料についても SEM 観察を行 ったが, 表面は非常に平坦で, 結晶粒界は観察されなかった.

\section{2 トリチウムの曝露}

Fig. 2 は試料のトリチウム懪露に用いた高真空装置の概 略図である. 試料を石英製の反応菅に入れ，前処理として温 度373〜 $673 \mathrm{~K}$ の間で, $50 \mathrm{~K}$ 刻みに昇温し，各温度で $10^{-6}$

* 平成17年11月 10 日 第46回真空に関する連合講演会で発表

*1 富山大学水素同位体科学研究センター （９30-8555 富山県富山市五福3190）

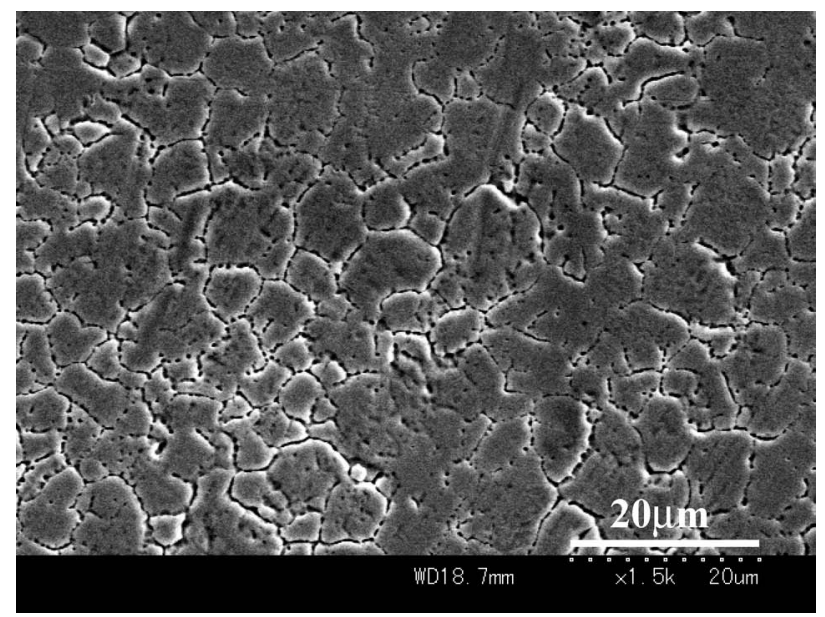

Fig. 1 SEM image of the as-received SS316 surface.

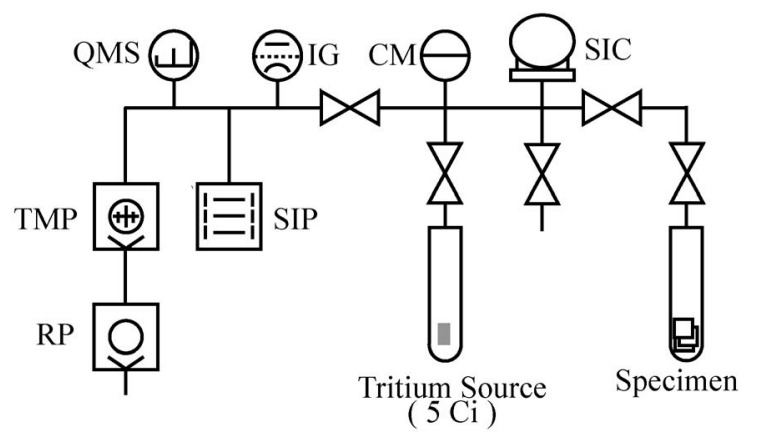

Fig. 2 The schematic diagram of the apparatus for exposure of SS316 specimen to tritium. QMS: quadruple mass spectrometer, IG: ionization gauge, CM: capacitance manometer, SIC: small ionization chamber, RP: rotary pump, TMP: turbo moleculer pump, SIP: sputter ion pump.

$\mathrm{Pa}$ 台の真空度に達するまで十分に脱力゙ス排気を行った。 そ の後, 装置内の残留ガスを十分に排気するため, 1〜2 日間 イオンポンプを用いて排気した後, トリチウムガスへの曝露 を行った，曝露に用いたガスは，24\%のトリチウムを含む 
水素ートリチウム混合ガスである. 試料への曝露は, 上記ガ スの圧力を 0.13 または $1.2 \mathrm{kPa}$ に保ち, 温度 $573 \mathrm{~K}$ で 3 時間 行った. 曝露後直ちに室温まで冷却した後トリチウムガスを 回収し，イオンポンプを用いて室温で 1 週間排気を行った.

\section{3 トリチウム分布の測定}

試料中のトリチウム分布は，エッチング法により調べた ${ }^{2)}$.

$50 \%$ 王水を用いて表面を腐食溶解し, 溶解液中に含をれる トリチウム量を液体シンチレーションカウンターで測定し た.エッチング後に試料の重さを計り，エッチングにより溶 出した試料の厚さを算出した.

\section{3. 結果 · 考察}

\section{1 表面未処理試料のトリチウム深さ分布}

$\mathrm{AR}$ 試料を曝露温度 $573 \mathrm{~K}$, 曝露圧力を 0.13 また $1.2 \mathrm{kPa}$ で，3 時間トリチウムガスに曝露した. Table 1 に示すよう に，トリチウム吸蔵量は，それぞれ $0.9 \mathrm{MBq}$ および7.8 MBq となった。

Fig. 3 に AR 試料中のトリチウム深さ分布を示す。図の 左右はトリチウム濃度とトリチウム濃度から換算した水素濃 度を表している，図に示すように曝露圧力に関係なく，表面 から数 $\mu \mathrm{m}$ までにトリチウム濃度の非常に高い領域が存在し た. XPS や AES による SS316の表面観察の報告によると， 表面から数 $\mathrm{nm}$ に酸化物層が存在していることが指摘されて いる3)。しかし，トリチウム濃度の高い領域が数 $\mu \mathrm{m}$ にも及

Table 1 Summary of loading results

\begin{tabular}{|c|c|c|c|c|}
\hline \multirow{2}{*}{$\begin{array}{c}\text { Surface } \\
\text { conditions }\end{array}$} & \multicolumn{3}{|c|}{ Loading conditions } & \multirow{2}{*}{$\begin{array}{c}\text { Average of tritium } \\
\text { inventory } \\
\mathrm{MBq} / \text { specimen }\end{array}$} \\
\hline & $\begin{array}{c}\text { Pressure } \\
\mathrm{kPa}\end{array}$ & $\underset{K}{\text { Temperature }}$ & $\begin{array}{l}\text { Time } \\
\text { hour }\end{array}$ & \\
\hline $\mathrm{AR}$ & 1.2 & 573 & 3 & $7.8(5)$ \\
\hline $\mathrm{AR}$ & 0.13 & 573 & 3 & $0.9(2)$ \\
\hline POL & 1.2 & 573 & 3 & $25.8(5)$ \\
\hline OX & 1.2 & 573 & 3 & $7.3(3)$ \\
\hline
\end{tabular}

$(\quad)$ number of specimen.

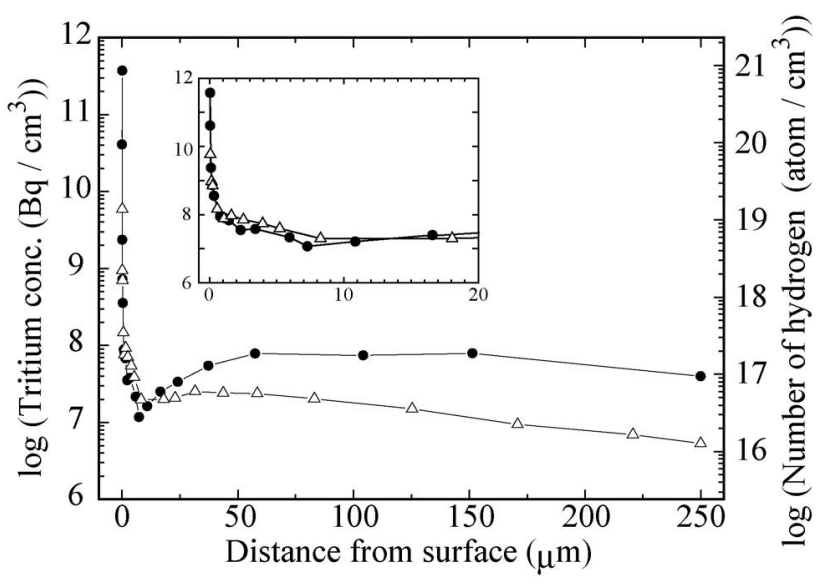

Fig. 3 Loading and etching results of tritium in as-received SS316 loaded at $573 \mathrm{~K}$ for 3 hours under the pressure of $\bullet$ $1.2 \mathrm{kPa}$ and $\triangle: 0.13 \mathrm{kPa}$.
ぶことから, 水素は単純に酸化物層に捕獲されているという わけではないと考えられる。

更に表面から深くなると, トリチウム濃度は急速に低下 し，表面から約 $10 \mu \mathrm{m}$ 付近で最低となった．との後トリチウ ム濃度は上昇し, 表面から $30 \sim 50 \mu \mathrm{m}$ の深さでほぼ均質に なった。

Reiter 等 ${ }^{4)}$ によって SS316中のトリチウムの拡散係数は,

$$
D\left(\mathrm{~m}^{2} \mathrm{~s}^{-1}\right)=5.9 \times 10^{-7} \exp \left(-\frac{51.9 \mathrm{kJmol}^{-1}}{\mathrm{R} T}\right)
$$

と報告されており, 曝露温度 $573 \mathrm{~K}$ における拡散係数 $D_{573 \mathrm{~K}}$ は $1.1 \times 10^{-11} \mathrm{~m}^{2} / \mathrm{s}$ となる. 従って, 3 時間曝露したときの 拡散距離は $x=\sqrt{2 \tau D}$ は $x=490 \mu \mathrm{m}$ となり, 試料の厚さに比 べて大きい.このため, 内部のトリチウム分布がほぼ均一で あると想定するのは妥当である。 また，本試料は曝露後 1 週間真空排気を行っている。（1)式から室温における拡散係 数を計算すると $D_{300 \mathrm{~K}}=5.4 \times 10^{-16} \mathrm{~m}^{2} / \mathrm{s}$ なので, Calder と Lewinの水素に対する拡散放出モデル5)を使って 1 週間排気 したときの試料中の濃度分布 $c(x, t)$ を計算すると, 濃度減 少が $0 \leq x \leq 50 \mu \mathrm{m}$ の範囲で起きることが示される. 従って, $10 \mu \mathrm{m}$ 付近でトリチウム濃度が谷形となる結果は, 1 週間の 真空排気によるトリチウム放出によると説明される.

\section{2 トリチウム濃度分布に与える表面処理の影響}

表面処理の異なる試料に対して温度 $573 \mathrm{~K}$, 圧力 $1.2 \mathrm{kPa}$ で 3 時間トリチウムガスに曝露した. Table 1 に示すように, $\mathrm{AR}, \mathrm{POL}$ および $\mathrm{OX}$ 試料のトリチウム吸蔵量は, それぞれ $7.8 ， 25.8$ および $7.3 \mathrm{MBq}$ であった. POL 試料中には AR と 比較して約 3 倍のトリチウムが存在したが，OX 試料のトリ チウム吸蔵量は, $\mathrm{AR}$ 試料とほとんど同じであった。一般に ステンレス試料表面には, 酸化物等の水素透過障壁が存在す るが，POL 試料では表面研磨により透過障壁が取り除かれ たため,トリチウム吸蔵量が AR 試料に対して大きくなっ たと考えられる。しかし，OX 試料では表面を研磨した後， 1 ヶ月間大気中に放置したことにより透過障壁が再生したた め, トリチウム吸蔵量が $\mathrm{AR}$ 試料のトリチウム吸蔵量と同 じになったと考えられる。

試料内部のトリチウム分布を Fig. 4 に示す。図の横軸は 表面からの深さ, 縦軸の左右はトリチウム濃度と水素濃度を 示している. また, 図中の破線は Reiter 等によって報告さ れたSS316におけるトリチウムの溶解度式,

$$
K_{\mathrm{s}}\left(\text { at.fr.Pa }{ }^{-1 / 2}\right)=5.8 \times 10^{-6} \exp \left(-\frac{13.1 \mathrm{kJmol}^{-1}}{\mathrm{R} T}\right)
$$

より計算された温度 $573 \mathrm{~K}$, 圧力 $1.2 \mathrm{kPa}$ におけるトリチウ ム吸蔵量を示している. 図に示すように表面処理にかかわら ず表面近傍にはトリチウム濃度の非常に高い領域が存在し， その濃度は上記式から予測される吸蔵量と比較して 2 桁以 上高かった. また, 表面近傍の最もトリチウム濃度の高い部 分の序列は $\mathrm{AR}>\mathrm{POL} \approx \mathrm{OX}$ の順であった. しかしながら， トリチウム濃度の高い層の厚さは約 $1 \mu \mathrm{m}$ であり, $\mathrm{AR}$, POL および OX ともほとんど大差はなかった。試料内部の トリチウム濃度は, AR 抽ざ OX でほとんど同じであり, POL の濃度は AR および OX の約 3 倍であった。 


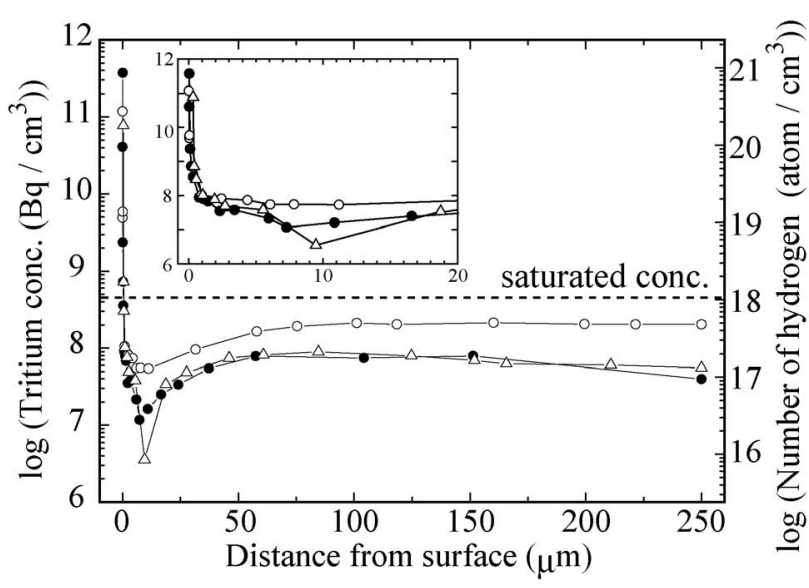

Fig. 4 Effect of surface conditions on the depth profiles of tritium in $\bullet$ : AR, $\bigcirc$ : POL and $\triangle$ : OX specimens.

ステンレス鋼材料の表面近傍には酸化物層や欠陥等のトラ ップサイトが存在することが知られている3 ${ }^{3)}$. 表面近傍の高 濃度のトリチウムは, これらトラップサイト上に大きな結合 エネルギーで捕獲されているので, 不動体水素と考えられ る.したがって真空中での水素ガスの放出現象は，この不動 体水素によるのではなく, この部分を通過できる動体水素に よると考えられる. また, 核融合炉では, 真空容器の壁に蓄
積するトリチウムの除染が課題である. 除染はこの動体水素 が主役となるので, 動体水素の挙動を研究することで, 水素 のガス放出の機構も明らかにできると思われる.

\section{4. ま と め}

表面処理の異なる試料に対し, トリチウムガスを用いて吸 蔵された水素の分布を可視化した。 その結果以下のことが分 かった；

1. 表面処理にかかわらず，表面近傍にトリチウム濃度の 非常に高い領域が存在する,

2. 研磨によって表面の水素透過障壁は除去されるが，一 ヶ月程度大気中に放置することにより障壁は再生される.

\section{〔文献}

1) K. Y. Wong, B. Hircq, R. A. Jalbert and W. T. Shmayda: Fus. Eng. and Design, 16 (1991) 155.

2) Y. Torikai, R.-D. Penzhorn, M. Matsuyama and K Watanabe: J. Nulc. Mater., 329-333 (2004) 1628.

3) Y. Hatano, T. Maetani and M. Sugisaki: Fus. Tecnol., 28 (1995) 1182.

4) F. Reiter, K. S. Forsey and G. Gervasini: "A compilation of tritium-material interaction parameters in fusion reactor materials" EUR 15217 EN (1993).

5) R. Calder and G. Lewin: Brit. J. Appl. Phys., 18 (1967) 1459. 